\title{
Renal antioxidant enzyme mRNA levels are increased in rats with experimental diabetes mellitus
}

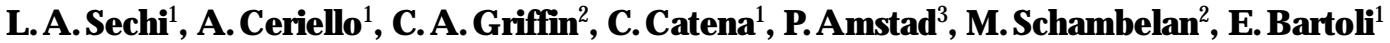 \\ ${ }^{1} \mathrm{D}$ epartment of I nternal M edicine, $U$ niversity of $U$ dine, $U$ dine, I taly \\ ${ }^{2}$ D ivision of E ndocrinology, San Francisco G eneral H ospital, U niversity of California San Francisco, San Francisco, \\ California, USA \\ ${ }^{3}$ Swiss I nstitute for Experimental Cancer R esearch (ISR E C), L ausanne, Switzerland
}

Summary Exposure to high glucose concentrations increases the $\mathrm{mRNA}$ levels of oxygen radical scavenging enzymes in cultured endothelial cells, suggesting a compensatory response to increased free radical production. To test the hypothesis that this response also occurs in vivo, Cu,Zn-superoxide dismutase $(\mathrm{Cu}, \mathrm{Zn}-\mathrm{SOD})$ and catalase mR N A levels, were measured in the kidneys of Sprague-D awley rats 17 days after intravenous injection of streptozotocin $(60 \mathrm{mg} /$ $\mathrm{kg}$ body weight) and compared with those of control rats. $D$ iabetic rats were either left untreated or given differing insulin regimens (2, 3-8, 6-10 IU/day) in two different experiments that were designed to achieve varying degrees of metabolic control. $C u, Z n-S O D$ and catalase mRNA levels were measured by Northern blot hybridization and standardized by $28 \mathrm{~S}$ ribosomal RNA determination. Renal Cu,Zn-SOD and catalase mRNA levels were significantly greater in untreated diabetic and in lowdose ( 2 IU /day) insulin-treated rats than in controls. Treatment with a moderate dose (3-8IU/day) of insulin normalized catalase but not $C u, Z n-S O D$ mR NA levels. The highest insulin regimen (6-10 IU/ day), in addition to achieving complete metabolic control as evidenced by normal growth and plasma glucose levels, normalized both catalase and $\mathrm{Cu}, \mathrm{Zn}$ SOD mRNA levels. Thus, in rats with streptozotocin-induced diabetes $C u, Z n-S O D$ and catalase renal mRNA levels are greater than in normal rats. This difference is prevented by sufficient insulin dosage to normalize plasma glucose and might be due to an increased production of free radicals. [D iabetologia (1997) 40: 23-29]

Keywords Catalase, messenger R NA, kidney, insulin, superoxide dismutase.
A Ithough the pathophysiology of diabetic complications is probably multifactorial, the results of in vitro [1], animal [2], and human [3] studies suggest a role for oxidative stress via an increased formation of free radicals. I ncreased generation of reactive oxygen metabolites such as superoxide anion and hydrogen peroxide has been shown to occur in diabetes mellitus in association with hyperglycaemia [4]. A $n$ increased

R eceived: 15 M ay 1996 and in revised form: 160 ctober 1996

Corresponding author: D r. L.A . Sechi, D epartment of Internal $M$ edicine, $U$ niversity of $U$ dine, School of M edicine, $O$ spedale Civile, Padiglione N uove M edicine, $33100 \mathrm{U}$ dine, I taly

A bbreviations: SOD, Superoxide dismutase; STZ, streptozotocin; $A O E$, endogenous antioxidant enzymes; SDS, sodium dodecyl sulphate; SSC, standard sodium citrate glucose concentration can induce formation of free radicals and activation of oxidative stress through nonenzymatic glycation of protein substrates [5], auto-oxidative glycation [6], activation of protein kinase C [7] and increased polyol pathway [8].

Excessive generation of reactive oxygen metabolites also plays a role in the pathophysiology of a variety of clinical and experimental renal diseases [9]. These diseases include acute and chronic, glomerular and tubular disorders through both immunological and non-immunological mechanisms. In the kidney, as in other organs, endogenous antioxidant enzymes (A O E s) protect cells against the toxic effect of free radicals and are an essential defence system against oxidant injury. Superoxide dismutases (SODs) exist in two forms containing copper/zinc ( $\mathrm{Cu}, \mathrm{Zn}$ SOD ) and manganese (M n-SOD), respectively, and 
transform the superoxide anion into hydrogen peroxide. Catalase catalyses the transformation of hydrogen peroxide to yield oxygen and water. Previous studies have indicated that the activity of SODs and catalase is modulated by many stimuli and is regulated to meet the biological need imposed by oxidant stress [10]. In some of these studies, transcriptional regulation of steady-state $\mathrm{mR} N \mathrm{~A}$ levels appeared to be a major determinant of local antioxidant enzyme levels [11, 12]. The present study was designed to evaluate the expression of the genes for $\mathrm{Cu}, \mathrm{Zn}$-SOD and catalase in kidney tissue of rats with experimentally induced diabetes which were either left untreated or given different insulin regimens designed to achieve varying degrees of metabolic control.

\section{Materials and methods}

A nimals. Male Sprague-Dawley rats (Bantin and Kingman, Fremont, Calif., USA ), ranging in weight from 150 to $200 \mathrm{~g}$, were maintained on standard rat chow and tap water ad libitum with 12 -h light/dark cycles in a quiet environment. D iabetes was induced by intravenous administration of streptozotocin (STZ) (Sigma, St. L ouis, M o., U SA ) 60 mg/kg body weight, dissolved in sodium citrate buffer $(0.1 \mathrm{~mol} / \mathrm{l}, \mathrm{pH} 4.5)$ at a concentration of $20 \mathrm{mg} / \mathrm{ml}$ immediately before use. Control rats, which were matched for age and weight at the time of ST Z administration, received an equal volume of the vehicle. $R$ ats were considered diabetic if blood glucose levels were greater than $6.7 \mathrm{mmol} / \mathrm{l} 72 \mathrm{~h}$ after the injection.

Experiment 1. D iabetic rats were further divided into two subgroups: untreated rats $(n=6)$, and rats to which human recombinant insulin (H umulin N, L illy, Indianapolis, Ind., U SA ) was administered once daily (at 20.00 hours) in moderate doses (3$8 \mathrm{IU} /$ day), that were adjusted to prevent severe hyperglycaemia $(n=6)$. Insulin treatment was begun 3 days after ST $Z$ injection. In control rats $(n=6)$ and untreated diabetic rats, blood glucose levels were measured every day by tail vein sampling ( $A$ ccu-chek bG, B io-D ynamics, B oehringer-M annheim, Indianapolis, Ind., USA ), whereas in the treated animals, insulin dosage was adjusted on the basis of daily determinations at 08.00 and 20.00 hours. Rats were killed by decapitation 17 days after administration of ST Z. Trunk blood was collected in fasted animals to measure plasma glucose and insulin levels. The kidneys were removed quickly, rinsed in phosphate buffered saline, weighed, and frozen in liquid nitrogen for subsequent R NA isolation.

Experiment 2. This experiment was performed with the same protocol except that one of the diabetic subgroups received a fixed low dose of insulin $(n=6)(2$ IU/day) to prevent ketosis, and the other subgroup $(n=6)$ a higher dose (6-10 IU/day), which was adjusted to achieve euglycaemia. Seventeen days after ST Z administration rats were killed and kidneys handled as indicated above.

RNA analysis. Total R NA was isolated from frozen tissue by a modification of the guanidine thiocyanate method of Chirgwin et al. [13], as described previously [14]. B riefly, after storage at $-80^{\circ} \mathrm{C}$, the tissue was homogenized in a solution containing $4 \mathrm{~mol} / \mathrm{l}$ guanidine thiocyanate, $25 \mathrm{mmol} / \mathrm{l}$ sodium citrate $(\mathrm{pH} \mathrm{7.0)}, 0.5 \% \mathrm{~N}$-lauroylsarcosine, and $0.1 \mathrm{~mol} / \mathrm{l}$ $\beta$-mercaptoethanol in a ratio of $16 \mathrm{ml} / \mathrm{g}$ tissue mass. Total nucleic acid was precipitated by the addition of $0.025 \%$ volume of $1 \mathrm{~mol} / /$ acetic acid, $50 \%$ volume of ethanol, and incubation at $-20^{\circ} \mathrm{C}$ for a minimum of $4 \mathrm{~h}$, followed by centrifugation at $12000 \mathrm{~g}$ at $-10^{\circ} \mathrm{C}$ for $20 \mathrm{~min}$. The pellet was drained briefly and resuspended in a solution containing $7.5 \mathrm{~mol} / \mathrm{l}$ guanidine hydrochloride, $25 \mathrm{mmol} / \mathrm{l}$ sodium citrate, and $4.5 \mathrm{mmol} / \mathrm{l}$ dithiothreitol, in a ratio of $8 \mathrm{ml} / \mathrm{g}$ tissue. Total R NA was then precipitated as indicated above. The resultant pellet was dissolved in sterile water and the total R NA concentration was quantitated by ultraviolet absorbance at $260 / 280 \mathrm{~nm}$. R NA integrity was verified by agarose gel electrophoresis.

A $0.45-k$ ilobase (kb) ${ }^{32} \mathrm{P}$-labelled antisense $\mathrm{Cu}, \mathrm{Zn}$-SO D CR NA was synthesized using a $X$ hol linearized SP65 vector containing the 450-bp Alul to Taql human Cu,Zn-SOD CDNA insert [15], as previously described [16]. A 0.468-kb ${ }^{32} \mathrm{P}$-labelled antisense catalase CR N A was synthesized using a $X$ hol linearized SP65 vector containing the 1250-bp Hind III to Pvull human catalase cDNA insert [17], as previously described [16]. Probe purification was performed by spin column centrifugation using a Sephadex G -50 R N A purification Q uick Spin column (Boehringer M annheim). Cu,Zn-SOD and catalase mR NA levels were quantitated by Northern blot hybridization analysis [14]. Nylon membranes were prehybridized in a solution containing $50 \mathrm{mmol} / \mathrm{l}$ Tris ( $\mathrm{pH} 7.5), 0.1 \%$ sodium pyrophosphate, $1 \%$ sodium dodecyl sulphate (SDS), $0.2 \%$ poly(vinylpyrrolidone), $0.2 \%$ Ficoll, $5 \mathrm{mmol} / \mathrm{EDTA}, 50 \%$ formamide, $0.2 \%$ bovine serum albumin, $1 \times$ standard sodium citrate (SSC), and $150 \mu \mathrm{g} / \mathrm{ml}$ denatured salmon sperm D NA at $65^{\circ} \mathrm{C}$ for $6 \mathrm{~h}$. $\mathrm{H}$ ybridization was performed using fresh prehybridization solution with the addition of radiolabelled $\mathrm{Cu}, \mathrm{Zn}$-SOD or catalase antisense CR NA at a concentration of $1 \times 10^{6}$ counts $\cdot \mathrm{min}^{-1} \cdot \mathrm{ml}^{-1}$. H ybridization was performed at $65^{\circ} \mathrm{C}$ for $16-18 \mathrm{~h}$. A fter hybridization membranes were washed sequentially at $65^{\circ} \mathrm{C}$, twice for $15 \mathrm{~min}$ with $2 \times \mathrm{SSC}-$ $0.1 \%$. SD S and twice for $15 \mathrm{~min}$ with $0.1 \times \mathrm{SSC}-0.1 \%$ SD S. A utoradiographs were obtained by exposing the membranes to Cronex X-ray film (D uPont, B oston, M ass., U SA ) with an intensifying screen at $-80^{\circ} \mathrm{C}$ for $15 \mathrm{~h}$ for $\mathrm{Cu}, \mathrm{Zn}-\mathrm{SOD}$ and for 5 days for catalase. Films were scanned with a laser densitometer (L K B U Itroscan, Piscataway, N.J., USA ). D uplicate membranes were prepared and hybridized with a ${ }^{32} \mathrm{P}$-labelled oligonucleotide probe complementary to bases $4011-4036$ of human $28 \mathrm{~S}$ ribosomal R N A [14].

Plasma glucose and insulin concentrations. Plasma glucose and insulin samples were obtained at time of killing. Plasma glucose was determined using a Y SI M odel 23A glucose autoanalyser (Yellow Springs I nstrument, Y ellow Springs, O hio, U SA ). Plasma insulin levels were determined by radioimmunoassay, using a double antibody technique [18].

Statistical analysis. D ata are presented as means \pm SE M . Comparisons between groups were done by analysis of variance (Statview, A bacus, Berkeley, Calif., USA ), and the relationships between blood glucose, plasma insulin, and mR NA levels were examined by linear regression analysis. D ifferences were considered to be statistically significant when $p$ was less than 0.05 .

\section{Results}

$\mathrm{H}$ yperglycaemia occurred within 3 days of ST Z administration in both experiments. B ecause of slight differences in age of rats and activity of STZ, blood 
Table 1. Body weight and blood glucose in control and diabetic rats with and without insulin treatment

\begin{tabular}{|c|c|c|c|c|c|c|c|c|c|c|}
\hline Group & $\begin{array}{l}\text { (R ats) } \\
\text { (n) }\end{array}$ & & Day 0 & D ay 4 & Day 6 & D ay 8 & D ay 10 & D ay 12 & D ay 14 & D ay 16 \\
\hline \multicolumn{11}{|l|}{ Experiment 1} \\
\hline Control & 6 & $\begin{array}{l}B W \\
B G\end{array}$ & $\begin{array}{l}153 \pm 2 \\
6.7 \pm 0.2\end{array}$ & $\begin{array}{l}183 \pm 2 \\
7.7 \pm 0.2\end{array}$ & $\begin{array}{l}198 \pm 3 \\
5.6 \pm 0.3\end{array}$ & $\begin{array}{l}213 \pm 2 \\
6.3 \pm 0.4\end{array}$ & $\begin{array}{l}230 \pm 1 \\
6.7 \pm 0.4\end{array}$ & $\begin{array}{l}243 \pm 3 \\
5.6 \pm 0.5\end{array}$ & $\begin{array}{l}255 \pm 3 \\
5.9 \pm 0.5\end{array}$ & $\begin{array}{l}270 \pm 3 \\
6.3 \pm 0.3\end{array}$ \\
\hline Diabetes & 6 & $\begin{array}{l}\text { BW } \\
B G\end{array}$ & $\begin{array}{l}152 \pm 2 \\
6.6 \pm 0.2\end{array}$ & $\begin{array}{c}162 \pm 2 \\
18.5 \pm 1.5\end{array}$ & $\begin{array}{c}173 \pm 3 \\
19.8 \pm 1.8\end{array}$ & $\begin{array}{c}180 \pm 3 \\
20.1 \pm 0.7\end{array}$ & $\begin{array}{c}185 \pm 4 \\
20.6 \pm 0.8\end{array}$ & $\begin{array}{c}193 \pm 4 \\
21.5 \pm 0.6\end{array}$ & $\begin{array}{c}201 \pm 7 \\
22.1 \pm 0.1\end{array}$ & $\begin{array}{l}211 \pm 8 \\
>22.2\end{array}$ \\
\hline $\begin{array}{l}\text { Diabetes + insulin } \\
\text { (3-8IU/day) }\end{array}$ & 6 & $\begin{array}{l}\text { BW } \\
B G\end{array}$ & $\begin{array}{l}149 \pm 1 \\
6.8 \pm 0.3\end{array}$ & $\begin{array}{c}163 \pm 6 \\
18.2 \pm 1.8\end{array}$ & $\begin{array}{c}183 \pm 5 \\
18.8 \pm 1.5\end{array}$ & $\begin{array}{c}204 \pm 4 \\
15.9 \pm 3.3\end{array}$ & $\begin{array}{l}216 \pm 5 \\
11.6 \pm 2.8\end{array}$ & $\begin{array}{l}240 \pm 6 \\
9.8 \pm 0.9\end{array}$ & $\begin{array}{c}257 \pm 8 \\
10.9 \pm 0.6\end{array}$ & $\begin{array}{c}268 \pm 7 \\
13.6 \pm 2.3\end{array}$ \\
\hline $\begin{array}{l}\text { Experiment } 2 \\
\text { Control }\end{array}$ & 6 & $\begin{array}{l}B W \\
B G\end{array}$ & $\begin{array}{l}198 \pm 2 \\
-\end{array}$ & $\begin{array}{l}237 \pm 2 \\
6.7 \pm 0.3\end{array}$ & $\begin{array}{l}249 \pm 3 \\
6.9 \pm 0.2\end{array}$ & $\begin{array}{l}261 \pm 3 \\
6.7 \pm 0.3\end{array}$ & $\begin{array}{l}276 \pm 4 \\
6.8 \pm 0.2\end{array}$ & $\begin{array}{l}288 \pm 3 \\
8.4 \pm 0.6\end{array}$ & $\begin{array}{l}297 \pm 4 \\
6.7 \pm 0.3\end{array}$ & $\begin{array}{l}304 \pm 6 \\
6.6 \pm 0.2\end{array}$ \\
\hline $\begin{array}{l}\text { Diabetes + insulin } \\
\text { ( } 2 \text { IU/day) }\end{array}$ & 6 & $\begin{array}{l}\text { BW } \\
\text { BG }\end{array}$ & $\begin{array}{l}198 \pm 2 \\
-\end{array}$ & $\begin{array}{c}201 \pm 2 \\
>22.2\end{array}$ & $\begin{array}{c}207 \pm 2 \\
>22.2\end{array}$ & $\begin{array}{l}210 \pm 3 \\
>22.2\end{array}$ & $\begin{array}{l}221 \pm 4 \\
>22.2\end{array}$ & $\begin{array}{c}230 \pm 6 \\
>22.2\end{array}$ & $\begin{array}{l}231 \pm 4 \\
>22.2\end{array}$ & $\begin{array}{c}235 \pm 8 \\
>22.2\end{array}$ \\
\hline $\begin{array}{l}\text { Diabetes + insulin } \\
\text { (6-10 IU/day) }\end{array}$ & 6 & $\begin{array}{l}B W \\
B G\end{array}$ & $\begin{array}{l}198 \pm 2 \\
-\end{array}$ & $\begin{array}{l}199 \pm 2 \\
>22.2\end{array}$ & $\begin{array}{c}222 \pm 3 \\
19.2 \pm 1.7\end{array}$ & $\begin{array}{c}236 \pm 2 \\
21.3 \pm 0.6\end{array}$ & $\begin{array}{l}264 \pm 4 \\
7.4 \pm 1.3\end{array}$ & $\begin{array}{l}276 \pm 4 \\
9.8 \pm 1.7\end{array}$ & $\begin{array}{c}283 \pm 4 \\
10.1 \pm 2.1\end{array}$ & $\begin{array}{l}300 \pm 4 \\
4.9 \pm 0.4\end{array}$ \\
\hline
\end{tabular}

Values are means \pm SE M . BW, B ody weight in $\mathrm{g} ; \mathrm{B} \mathrm{G}$, blood glucose in $\mathrm{mmol} / \mathrm{l}$. B lood glucose was measured by tail vein sampling and A ccu-Check.

Table 2. $E$ ffect of STZ-induced diabetes with and without insulin treatment on body weight, kidney weight/body weight ratio, plasma glucose, insulin concentration, renal $\mathrm{Cu}, \mathrm{Zn}-\mathrm{SO} D \mathrm{mRNA}$, renal catalase mRNA, and renal $28 \mathrm{~S}$ rR NA in the rat

\begin{tabular}{|c|c|c|c|c|c|c|c|c|}
\hline Group & $\begin{array}{l}R \text { ats } \\
(n)\end{array}$ & $\begin{array}{l}\text { Body } \\
\text { weight } \\
\text { (g) }\end{array}$ & $\begin{array}{l}\text { Plasma } \\
\text { glucose } \\
\text { (mmol/l) }\end{array}$ & $\begin{array}{l}\text { K idney weight/ } \\
\text { body weight } \\
\text { ratio }(\times 1000)\end{array}$ & $\begin{array}{l}\text { Plasma } \\
\text { insulin } \\
\text { (pmol/l) }\end{array}$ & $\begin{array}{l}\text { Cu,Zn-SOD } \\
\text { mR NA } \\
\text { (scanner units) }\end{array}$ & $\begin{array}{l}\text { Catalase } \\
\text { mR NA } \\
\text { (scanner } \\
\text { units) }\end{array}$ & $\begin{array}{l}\text { 28S rR N A } \\
\text { (scanner } \\
\text { units) }\end{array}$ \\
\hline $\begin{array}{l}\text { Experiment } 1 \\
\text { Control }\end{array}$ & 6 & $270 \pm 3$ & $8.1 \pm 0.2$ & $6.8 \pm 0.3$ & $52 \pm 5$ & $14.5 \pm 0.8$ & $4.3 \pm 0.5$ & $14.0 \pm 0.6$ \\
\hline D iabetes & 6 & $211 \pm 8^{a}$ & $29.6 \pm 2.6^{a}$ & $9.9 \pm 0.2^{\mathrm{a}}$ & $29 \pm 4^{b}$ & $39.4 \pm 5.2^{c}$ & $7.2 \pm 0.6^{c}$ & $13.2 \pm 0.8$ \\
\hline $\begin{array}{l}\text { Diabetes + insulin } \\
\text { (3-8IU/day) }\end{array}$ & 6 & $268 \pm 7$ & $14.4 \pm 2.8$ & $7.7 \pm 0.3$ & $62 \pm 4$ & $33.7 \pm 3.6^{c}$ & $5.0 \pm 0.4$ & $13.2 \pm 0.5$ \\
\hline $\begin{array}{l}\text { Experiment } 2 \\
\text { Control }\end{array}$ & 6 & $304 \pm 6$ & $6.9 \pm 0.2$ & $7.6 \pm 0.2$ & $35 \pm 3$ & $10.7 \pm 1.2$ & $4.4 \pm 0.3$ & $15.4 \pm 1.0$ \\
\hline $\begin{array}{l}\text { Diabetes + insulin } \\
\text { (2 IU/day) }\end{array}$ & 6 & $235 \pm 8^{a}$ & $26.1 \pm 1.0^{\mathrm{a}}$ & $11.4 \pm 0.3^{\mathrm{a}}$ & $10 \pm 1^{\mathrm{a}}$ & $18.3 \pm 2.6^{d}$ & $5.6 \pm 0.3^{e}$ & $14.9 \pm 0.7$ \\
\hline $\begin{array}{l}\text { Diabetes + insulin } \\
\text { (6-10 IU/day) }\end{array}$ & 6 & $300 \pm 4$ & $6.2 \pm 0.6$ & $8.3 \pm 0.1^{c}$ & $80 \pm 10^{a}$ & $12.9 \pm 1.3$ & $3.4 \pm 0.4$ & $15.7 \pm 0.8$ \\
\hline
\end{tabular}

Values are means \pm SE M. M easurements of body weight, kidney weight, plasma glucose, and plasma insulin were done at time of death. Plasma glucose and plasma insulin were measured on trunk blood. Comparisons were done by analysis of variance. Due to differences in the age of the rats, activity of
STZ, acitivity of ${ }^{32} \mathrm{P}$ at time of use, and duration of exposure on film no comparisons could be done between experiment 1 and experiment 2. mRNA values are normalized with 285 rRNA. $\quad{ }^{a} p<0.001 ; \quad{ }^{b} p<0.005 ; \quad{ }^{c} p<0.01 ; \quad{ }^{d} p<0.025 ;$ ${ }^{e} p<0.05$ vs the respective control glucose values of diabetic rats were higher in experiment 2 than in experiment 1 . D uring the experiments, hyperglycaemia persisted in both the untreated diabetic rats and in those that received low-dose ( $2 \mathrm{IU} /$ day) insulin therapy (Table 1), was less severe in the subgroup that received moderate doses (3-8 IU /day) of insulin, and was ameliorated completely in those that received the highest dose (6-10 IU/day) (Table 1). R ats treated with the two highest doses of insulin gained weight rapidly, reaching values not significantly different from control animals at the end of the experimental period (Table 1, Table 2). The kidney weight/body weight ratio was significantly increased in both the untreated diabetic rats and in those that received low-dose insulin therapy, indicating the presence of renal hypertrophy that was prevented by both moderate- and high-dose insulin regimen (Table 2 ). Plasma insulin levels were reduced significantly in both the untreated and lowdose insulin-treated animals, equivalent to controls in those that received moderate doses, and significantly greater than controls in those that received the highest doses of insulin (Table 2).

Renal Cu,Zn-SOD mRNA levels were significantly greater in untreated diabetic and in low-dose (2 IU/day) insulin-treated rats than in controls (Table 2, Fig.1). Treatment with a moderate dose (3-8IU/day) of insulin decreased Cu,Zn-SOD mR NA levels but did not normalize them (Table 2 , Fig. 1). The highest insulin regimen (6-10 IU/day), in 


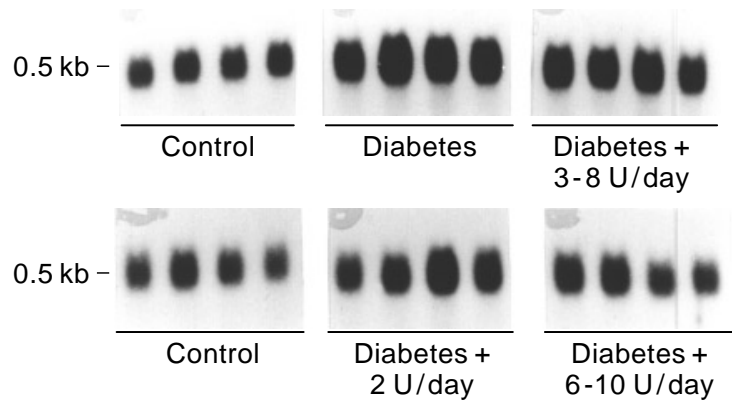

Fig. 1. Representative Northern blot of $\mathrm{Cu}, \mathrm{Zn}-\mathrm{SOD}$ mRNA extracted from kidney of control and diabetic rats treated with different insulin doses in experiment 1 (upper panel) and experiment 2 (lower panel). Total R N A $(40 \mu \mathrm{g})$ was electrophoresed through a $1 \%$ agarose gel, transferred to a nylon filter, and hybridized with a ${ }^{32} \mathrm{P}$-labelled $\mathrm{Cu}, \mathrm{Zn}$-SOD probe at $65^{\circ} \mathrm{C}$. The probe was synthesized using a $X$ hol linearized SP65 vector containing 450-bp Alul to Taq I human Cu,ZnSOD CD NA insert. Size of bands indicated in kb

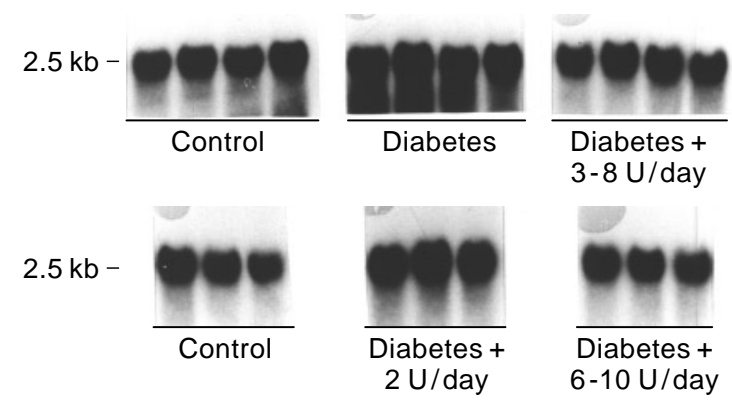

Fig. 2. Representative Northern blot of catalase mRNA extracted from kidneys of control and diabetic rats treated with different insulin doses in experiment 1 (upper panel) and experiment 2 (lower panel). Total RNA $(40 \mu \mathrm{g})$ was electrophoresed through a $1 \%$ agarose gel, transferred to a nylon filter, and hybridized with a ${ }^{32} \mathrm{P}$-labelled catalase probe at $65^{\circ} \mathrm{C}$. The probe was synthesized using a $X$ hol linearized SP 65 vector containing the 1250 -bp $\mathrm{H}_{\text {ind III }} \mathrm{t}_{0}$ Pvull human catalase CD NA insert. Size of bands is indicated in $\mathrm{kb}$

addition to achieving complete metabolic control, as ascertained by normal weight growth and blood glucose levels, normalized Cu,Zn-SOD mRNA levels. Similar to $C u, Z n-S O D$, catalase mRNA levels were significantly greater in untreated diabetic and in lowdose insulin-treated rats than in controls (Table 2, Fig. 2). Treatment with both moderate and high-dose insulin normalized catalase mR NA levels (Table 2, Fig. 2). A s shown in Table 2, $28 \mathrm{~S}$ rR N A levels were not affected by ST Z-diabetes and are an appropriate standard by which to normalize mR N A levels in diabetic rats.

In both experiments, no significant correlations between plasma glucose and renal mR NA levels of both $C u, Z n-S O D$ and catalase where found when only the diabetic groups were considered. When all the rat groups were included, renal mR NA levels of $\mathrm{Cu}, \mathrm{Zn}$-SOD and catalase were directly correlated in
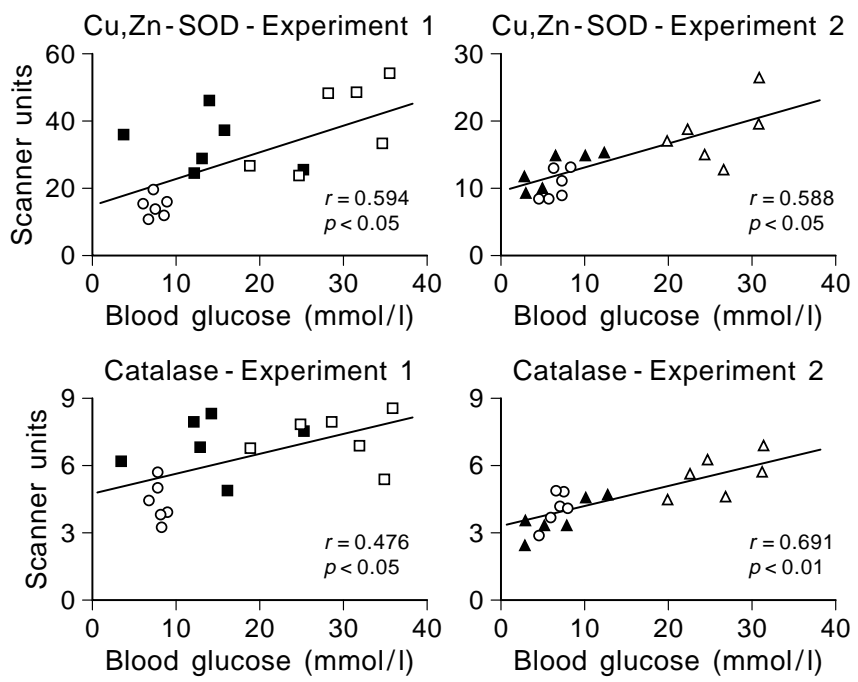

Fig. 3. Relationships between final levels of plasma glucose and the renal, $\mathrm{Cu}, \mathrm{Zn}$-SOD mRNA levels (upper panels) and the renal catalase $\mathrm{mR} N \mathrm{~A}$ levels (lower panels) in experiment 1 (left panels) and experiment 2 (right panels). Control rats, $O$; untreated diabetic rats, $\square$; diabetic rats treated with moderate insulin dose (3-8 IU /day), $\mathbf{0}$; diabetic rats treated with low insulin dose ( 2 IU /day), $\triangle$; diabetic rats treated with high insulin dose (6-10 IU/day),

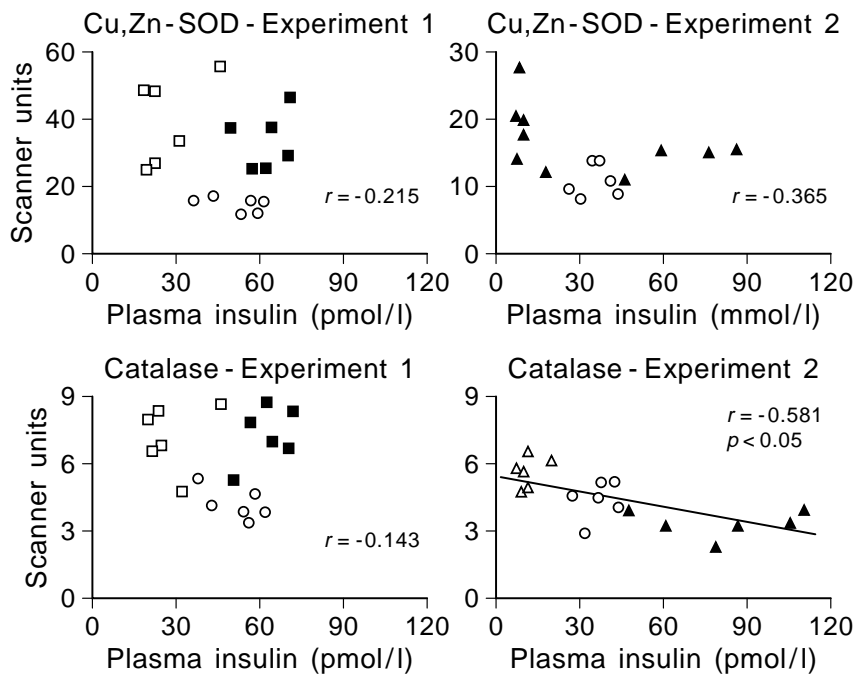

Fig. 4. R elationships between final levels of plasma insulin and the renal $\mathrm{Cu}, \mathrm{Zn}$-SO D mR N A levels (upper panels) and the renal catalase mR NA levels (lower panels) in experiment 1 (left panels) and experiment 2 (right panels). Control rats, $\bigcirc$; untreated diabetic rats, $\square$; diabetic rats treated with moderate insulin dose (3-8IU/day), $\mathbf{\square}$; diabetic rats treated with low insulin dose ( 2 IU/day), $\triangle$; diabetic rats treated with high insulin dose (6-10 IU/day),

both experiment $1(r=0.55, p<0.05)$ and experiment 2 ( $r=0.47, p<0.05)$. I $n$ both experiments, a significant positive correlation was observed between the level of renal Cu,Zn-SOD (experiment 1: $r=0.59, p<0.05$; experiment 2: $r=0.59, p<0.05$ ) and catalase (experiment $1: r=0.48, \quad p<0.05$; 
experiment 2: $r=0.69, p<0.01$ ) $\mathrm{mRNA}$ and the blood concentration of glucose obtained at the time of death (Fig.3). A significant inverse correlation was observed between catalase mRNA and plasma insulin only in experiment 2 (experiment $1: r=-0.14$; experiment 2: $r=-0.58, p<0.05$ ) (Fig. 4). No significant correlation was found between $\mathrm{Cu}, \mathrm{Zn}$-SO D and insulin (experiment 1: $r=-0.22$; experiment 2: $r=$ -0.37) (Fig.4). In both experiments, no correlations were observed between renal mR NA levels of both enzymes and the kidney weight/body weight ratios.

\section{Discussion}

The results of this study indicate that the steady-state mRNA levels of Cu,Zn-SOD and catalase are increased in the kidneys of rats with STZ-induced diabetes in comparison to control rats. In diabetic rats, treatment with an insulin dose designed to achieve euglycaemia normalized the mRNA levels of both antioxidant enzymes. A significant direct correlation was observed between the levels of blood glucose at the end of the experiments and renal mRNA levels of both $\mathrm{Cu}, \mathrm{Zn}-\mathrm{SOD}$ and catalase, suggesting that high glucose concentration in plasma and/or tissue affects the gene expression of renal A OE s. Treatment with a moderate dose of insulin normalized catalase but not Cu,Zn-SOD mR NA levels, suggesting a different threshold in the response of these genes to glucose concentration. Exposure to high glucose concentrations increases both the activity and the mR NA levels of $\mathrm{Cu}, \mathrm{Zn}$-SOD and catalase in cultured endothelial cells, suggesting a compensatory effect to counter increased free radical production [19]. The present findings extend this observation to an in vivo setting showing that the gene expression of antioxidant enzymes is associated with greater glucose concentration also in animal tissues.

Increased formation of reactive oxygen metabolites occurs in diabetes for reasons related to the presence of increased glucose concentration in plasma and tissues [4]. It is known that glycated proteins, which are increased in diabetes as a result of nonenzymatic glycation, may form superoxide anions under physiological conditions [5]. In addition to inducing direct glycation reactions, monosaccharides can enolize and thereby reduce molecular oxygen, yielding hydrogen peroxide and free radicals in a reaction known as "auto-oxidative glycation" [6]. Further hypothetical mechanisms that might account for increased free radical generation in diabetic tissues are the hyperglycaemia-induced activation of protein kinase $C[7,20]$ and activation of the polyol pathway [8]. B ecause excessive generation of reactive oxygen metabolites is the most frequent condition in which the activity and gene expression of free radical scavenging enzymes is increased [10] and greater levels of antioxidant enzymes are strong indicators of increased formation of reactive oxygen species [21], the increase in AOE mRNA levels that we found in kidneys of diabetic rats might well occur as a result of an excessive production of free radicals.

The activity of A O E s has been measured in the renal tissue of rats with chemically induced diabetes. $\mathrm{Cu}, \mathrm{Zn}-\mathrm{SOD}$ has been found to be decreased $[22,23]$ or comparable to normal controls [24-26], whereas catalase has been found to be decreased [22, 27], increased [23], or comparable to normal [26]. The basis for the discrepancies of these studies is not clear, although differences in severity, duration, and treatment of diabetes may be indicated. In addition, analysis of data from various investigators suggests the possibility that there may be transient changes in AOE activity after induction of diabetes. For instance, decrease in tissue $A O E$ s may occur as a result of the acute toxicity of ST Z or acute hyperglycaemia [24], whereas, after prolonged hyperglycaemia, induction of A OEs might occur to meet the oxidant stress [28]. The findings on A OE activity also appear to be in conflict with the observation of an increased mR NA level of both $\mathrm{Cu}, \mathrm{Zn}-\mathrm{SO} D$ and catalase in diabetic kidneys. In this respect, it is important to note that, in addition to the already mentioned differences in the experimental protocols, other factors might be involved. First, A OEs might undergo nonoxidative glycation and this could impair their activity when this activity is assayed in vitro. Second, increased oxidative stress, as indicated by increased levels of lipid peroxides and 8-hydroxydeoxiguanosine in plasma, urine [29-31], and renal tissue [32, 33] of diabetic rats, might interfere with the in vitro assessment of A O E activity. Finally, an increase in A O E s has been shown to be the commonest response to an increased oxidative stress in other rat models of kidney disease characterized by early and massive proteinuria [9, $34,35]$ and therefore it might be reasonable to expect a similar change in diabetes.

It is important to note that, in this study, renal mR NA levels of A OE shave been measured in whole tissue extracts. O ne might then argue that, since diabetic nephropathy involves mainly the renal glomeruli, the increased AOE mR NA levels that we found in diabetic rats might reflect glucose-mediated processes unrelated to glomerulopathy. With regard to this observation, we want to point out that glomerular abnormalities found in early diabetic nephropathy are characterized mainly by an increased renal and glomerular blood flow occurring as a consequence of reduced arteriolar resistance [36]. Therefore, the abnormality resides outside the glomerulus per se, most likely in vascular structures, such as afferent and efferent arterioles, but also in larger vessels that are ubiquitous in the kidney. M oreover, renal tubules are not completely spared by the pathological process [37] and could either be the source or the target of 
biochemical damage due to high glucose. Finally, although A OE s are reasonably compartmentalized, biological membranes are highly permeable to oxidants [38] and thus the site of oxidant injury may be distant from the site of oxidant generation.

Excessive amounts of reactive oxygen species may be generated as a consequence of metabolic adaptation of surviving nephrons to loss of renal mass. Indeed, there are studies in the remnant kidney model in which increased urinary excretion of lipid peroxidation products has been shown as a likely result of increased generation of reactive oxygen species [39]. A lthough it is possible that the changes in $A O E$ mR NA levels that we have observed in this study are a consequence of renal hypertrophy rather than being due to diabetes per se, substantial biochemical $[40,41]$, morphological $[42,43]$, and functional [36, 44] differences between compensatory renal hypertrophy and diabetic renal hypertrophy argue against this possibility. M oreover, although the present study does not clarify the role of diabetic renal hypertrophy in the induction of $A O E$ gene expression, absence of correlations between the mRNA levels of $\mathrm{Cu}, \mathrm{Zn}$ SO D and catalase and the kidney weight/body weight ratios makes this role unlikely.

M ost of the previous studies concerning the regulation of SOD activity and gene expression focused on the $\mathrm{Mn}$-dependent isoenzyme since this was considered to be the inducible enzyme. The synthesis of the $\mathrm{Cu}, \mathrm{Zn}$-dependent isoenzyme was considered to be largely constitutive [45]. I n contrast with this view some studies have shown that the activity of $\mathrm{Cu}, \mathrm{Zn}$ SO D is regulated in lung tissue as well as that of $M$ nSO $D$ [46]. The present findings in a rat model of renal disease confirm that the expression of $\mathrm{Cu}, \mathrm{Zn}-\mathrm{SOD}$ gene can be regulated.

There is evidence that active oxygen metabolites are involved in the toxic action of STZ on the pancreatic islets [47]. It might then be argued that a similar effect might cause activation of expression of A OES in the kidney of rats injected with STZ, independent of blood glucose concentration. This possibility is unlikely for three reasons. First, there is evidence that ST Z is cleared rapidly from the body after accumulation in the pancreas [47] and therefore it is difficult to believe that its effects persist for 2 weeks. Second, the levels of A OE mR NA were normalized by treatment with high doses of insulin in rats that received identical doses of STZ, and this argues strongly against the possibility of an STZ-mediated effect. Third, we observed a significant correlation between blood glucose concentration at the end of the experiment and $\mathrm{Cu}, \mathrm{Zn}-\mathrm{SOD}$ and catalase mRNA levels, suggesting that the expression of $A O E$ genes is under the influence of glucose.

In conclusion, $\mathrm{Cu}, \mathrm{Zn}-\mathrm{SOD}$ and catalase renal mRNA levels are associated with higher blood glucose levels in rats with STZ-induced diabetes. It is possible that an increased production of reactive oxygen metabolites accounts for this increase in $A O E$ gene expression. R eactive oxygen metabolites might be involved in the pathophysiology of diabetic nephropathy similar to other renal pathological conditions.

A cknowledgements. We are grateful to Dr. C.Grunfeld for measuring plasma insulin concentrations. This research was supported by C.N.R. (Consiglio Nazionale delle Ricerche) $\mathrm{G}$ rant (92.01096.CTO4 and 94.084231.CT 04), and National H eart, L ung, and B lood Institute G rant (H L-11046). L.A.S. is recipient of a R esearch $G$ rant from the Ferrero Foundation and of a Fulbright Fellowship A ward. Part of this work was presented at the $27^{\text {th }} A$ nnual M eeting of the A merican Society of N ephrology (O rlando, F lorida, O ctober 1994) and has been published as an abstract in the proceedings of this meeting.

\section{References}

1. Lorenzi M, Nordberg JA, Toledo S (1987) High glucose prolongs cell cycle traversal of cultured human endothelial cells. D iabetes 36: 1261-1267

2. L ow PA, Nickander K K (1991) Oxygen free radical effects in sciatic nerve in experimental diabetes. Diabetes 40: 873-877

3. Jennings PE, Jones A F, Florkowski CM , L unec J, B arnett $\mathrm{A} \mathrm{H}$ (1987) Increased diene conjugates in diabetic subjects with microangiopathy. D iabet M ed 4: 452-456

4. G iugliano D, Ceriello A , Paolisso G (1996) O xidative stress and diabetic vascular complications. Diabetes Care 19: 257-267

5. Sakuzay T, T suchiya S (1988) Superoxide production from nonenzymatically glycated proteins. FE BS (lett) 236: 406410

6. Wolff SP, D ean RT (1987) G lucose autoxidation and protein modification. The potential role of "autooxidative glycosylation" in diabetes. B iochem J 245: 243-250

7. D erubertis FR , Craven PA (1994) A ctivation of protein kinase $C$ in glomerular cells in diabetes. M echanisms and potential links to the pathogenesis of diabetic glomerulopathy. D iabetes 43: 1-8

8. G harary A, L uo J, G ong Y, Chakrabarti S, Sima A A F, M urphy LJ (1989) Increased renal aldose reductase activity, immunoreactivity, and mR NA in streptozotocin-induced diabetic rats. $D$ iabetes 38: 1067-1071

9. I chikawa I, K iyama S, Y oshioka T (1993) R enal antioxidant enzymes: their regulation and function. K idney Int 45: 1-9

10. Touati D (1992) R egulation and protective role of the microbial superoxide dismutases. In: A candalios J G (ed) Current communications in cell and molecular biology. V. M olecular biology and free radical scavenging systems, Cold Spring $\mathrm{H}$ arbor Laboratory Press, Cold Spring $\mathrm{H}$ arbor, pp 231-261

11. Y oshioka T, H omma T, M eyrick B et al. (1994) O xidants induce transcriptional activation of manganese superoxide dismutase in glomerular cells. K idney Int 46: 405-413

12. Y oshioka T, K anamura T, M eyrick BO et al. (1994) Induction of manganese superoxide dismutase by glucocorticoids in glomerular cells. K idney Int 45: 211-219

13. Chirgwin J M, Przybyla AE, McD onald RJ, Rutter WJ (1979) Isolation of biologically active ribonucleic acid from sources enriched in ribonuclease. Biochemistry 18: 5294-5299

14. Sechi LA, G riffin CA, Schambelan M (1994) E ffect of dietary sodium chloride on insulin receptor number and 
mR NA levels in rat kidney. A m J Physiol 266 (R enal Fluid Electrolyte Physiol): F 31-F 38

15. Sherman L, L evanon D, L ieman-H urwitz J, D afni N, G roner $Y$ (1984) Human $\mathrm{Cu} / \mathrm{Zn}$ superoxide dismutase gene: molecular characterization of its two mR NA species. Nucleic A cids R es 12: 9349-9365

16. A mstad P, Peskin A, Shah G et al. (1991) The balance between $\mathrm{Cu}, \mathrm{Zn}$-superoxide dismutase and catalase affects the sensitivity of mouse epidermal cells to oxidative stress. Biochemistry 30: 9305-9313

17. Korneluk R, Q uan F, L ewis W et al. (1984) I solation of human fibroblast catalase CD N A clones. Sequence of clones derived from spliced and unspliced DNA.J Biol Chem 259: 13819-13823

18. Feingold KR, Soned M, Staprans M et al. (1989) Effect of tumor necrosisfactor (TNF) on lipid metabolism in the diabetic rat: evidence that inhibition of adipose tissue lipoprotein lipase activity is not required for TNF-induced hyperlipidemia. J Clin Invest 3: 1116-1121

19. Ceriello A, dello R usso P, A mstad P, Cerutti $P$ (1996) High glucose induces antioxidant enzymes in human endothelial cells in culture. D iabetes 45: 471-477

20. $\mathrm{H}$ a H, Y oon SJ, K im K H (1994) H igh glucose can induce lipid peroxidation in the isolated rat glomeruli. Kidney Int 46: $1620-1626$

21. Beckman J S, Freeman BA (1986) A ntioxidant enzymes as mechanic probes of oxygen-dependent toxicity. In: Taylor A E, M atalon S, Ward P (eds) Physiology of oxygen radicals. A merican Physiological Society, pp 39-53

22. Wohaieb SA , Godin DV (1987) A Iterations in free radical tissue-defense mechanisms in streptozotocin-induced diabetes in rat. Effects of insulin treatment. Diabetes 36: 1014-1018

23. M atkovics B, Varga SI, Szabo L, Witas H (1982) The effect of diabetes on the activities of the peroxide metabolism enzymes. H orm M etab R es 14: 77-79

24. Crouch R, K imsey G, Priest D G, Sarda A, Buse M G (1978) Effect of streptozotocin on erythrocyte and retinal superoxide dismutase. Diabetologia 15: 563-572

25. Nishida T, Nakagawa S, M anabe R (1984) Superoxide dismutase activity in diabetic rat retina. J pn J 0 phthalmol 28 : 377-382

26. D ohi T, K awamura $K$, M orita $K$, O kamoto $H$, T sujimoto $A$ (1988) A Iterations of the plasma selenium concentrations and the activities of tissue peroxide metabolism enzymes in streptozotocin-induced diabetic rats. $\mathrm{H}$ orm M etab R es 20: 671-675

27. L oven D, Schedl H, Wilson $H$ et al. (1986) Effect of insulin and oral glutathione on glutathione levels and superoxide dismutase activities in organs of rats with streptozotocin-induced diabetes. Diabetes 35: 503-507

28. Pieper $G M$, J ordan $M$, D ondlinger $L A$, A dams $M B, R$ oza A M (1995) Peroxidative stress in diabetic blood vessels. Reversal by pancreatic islet transplantation. Diabetes 44 : 884-889

29. O hkawa H, O hishi N, Yagi K (1979) A ssay for lipid peroxides in animal tissues by thiobarbituric acid reaction. A nal Biochem 95: 351-358
30. K arpen CW, Pritchard KA J r, A rnold JH, Cornwell D G, Panganamala RV (1982) R estoration of the prostacyclin/ thromboxane $\mathrm{A}_{2}$ balance in the diabetic rat: influence of vitamin E. D iabetes 31: 947-951

31. Y oung IS, Torney JJ, Trimble R R (1992) The effect of ascorbate supplementation on oxidative stress in the streptozotocin diabetic rat. Free $\mathrm{R}$ adical $\mathrm{B}$ iol $\mathrm{M}$ ed 13: 41-46

32. H a H , K im K H (1995) R ole of oxidative stress in the development of diabetic nephropathy. K idney Int 48 [Suppl 51]: S18-S21

33. Ha H, Kim C, Son Y, Chung M H, Kim KH (1994) DNA damage in the kidneys of diabetic rats exhibiting microalbuminuria. Free R adical B iol M ed 16: 271-274

34. Diamond J R, B onventre JV, K arnovsky M J (1986) A role for oxygen free radicals in aminonucleoside nephrosis. Kidney Int 29: 478-483

35. Shah S (1989) R ole of reactive oxygen metabolites in experimental glomerular disease. K idney Int 35: 1093-1106

36. H ostetter TH , Troy LJ, B renner B M (1981) G lomerular hemodynamics in experimental diabetes mellitus. Kidney Int 19: 410-415

37. H arris R C, B renner BM, Seifter J L (1986) Sodium-hydrogen exchange and glucose transport in renal microvillus membrane vescicles from rats with diabetes mellitus. J Clin Invest 77: 724-730

38. D eby C, Goutier R (1990) New perspectives on the biochemistry of superoxide anion and the efficiency of superoxide dismutases. Biochem Pharmacol 39: 399-405

39. H arris D CH , Chan L, Schrier RW (1988) R emnant kidney hypermetabolism and progression of chronic renal failure. A m J Physiol 254 (R enal Fluid Electrolyte Physiol): F267F276

40. Tomashevsky P, Tannebaum M (1969) Macromolecular metabolism in compensatory renal hypertrophy: I Protein synthesis. Lab Invest 21: 358-364

41. Seyer-H ansen K (1976) R enal hypertrophy in streptozotocin diabetic rats. Clin Sci M ol M ed 51: 551-555

42. O sterby R, G undersen H J G (1980) Fast accumulation of basement membrane material and the rate of morphological changes in acute experimental diabetic glomerular hypertrophy. Diabetologia 18: 493-500

43. Vancura P, M iller WL, Little JW (1970) Contribution of glomerular and tubular R NA synthesis to compensatory renal growth. A m J Physiol 19 (Renal Fluid Electrolyte Physiol): F 78-F 83

44. N orthrup TE, M alvin R L (1976) Cellular hypertrophy and renal function during compensatory renal growth. A m J Physiol 231 (Renal Fluid Electrolyte Physiol): F1191F1195

45. B annister J V, B annister WH, R otilio G (1987) A spects of the structure, function, and applications of superoxide dismutase. CR C Crit R ev B iochem 22: 111-180

46. Sjostrom K , Crapo J D (1981) A daptation to oxygen by preexposure to hypoxia: enhanced activity of manganese superoxide dismutase. Bull Eur Physiopathol Respir 17: 111-116

47. O berley LW (1988) Free radicals and diabetes. Free R adical Biol Med 5: 113-124 